Igor Kissin MD PH D, C. Reid Kerr Ms, Lloyd R. Smith MA

\title{
Assessment of anaesthetic action of morphine and fentanyl in rats
}

In 150 Sprague-Dawley rats, morphine and fentanyt dose-effect curves were determined for the following three end points - prevention of purposeful movement response to a noxious stimulus (PM), loss of righting reflex $(R R)$, and prevention of heart rate increase to a noxious" stimulus (HR). Accordingly, for each agent, three series of experiments were performed with intravenous administration of the following doses: morphine 3-10 $\mathrm{mg}^{\prime} \mathrm{kg}^{-1}$ for PM, 3-10 $\mathrm{mg} \cdot \mathrm{kg}^{-1}$ for $\mathrm{HR}, 35-55$ $m g \cdot \mathrm{kg}^{-1}$ for $R R$; fentanyl - 5-15 $\mu \mathrm{g}^{\prime} \mathrm{kg}^{-1}$ for $P M$, $18-30 \mu \mathrm{g} \cdot \mathrm{kg}^{-1}$ for RR, 200-400 $\mathrm{\mu g} \cdot \mathrm{kg}^{-1}$ for HR. Doseeffect curves were calculated with the use of probit procedure and potency ratios were determined on the bases of EDSO values. It was found that potency ratios of morphine and fentany! are different for the studied end points. The ratios of RR ED50 to PM ED50 were 7.8 for morphine vs 2.4 for fentanyl $(p<0.001)$, the ratios of $H R$ ED50 to PM ED50 were 1 and 33, respectively $(p<$ $0.001)$. These results suggest that blockade of movement response to noxious stimulation (which is usually regarded as an index for analgesic action of opioids) and blockade of heart rate increase to noxious stimulation (which is one of the goals of anaesthesia) is not necessarily induced by intravenous narcotic anaesthetics through the same mechanism. Aralgesic potency of intravenous narcotic anaesthetics, determined on the basis of their ability to block movement response to a noxious stimulus, may not reflect the strength of their action regarding such an important component of anaesthesia as autonomic unresponsiveness to surgical stimulation.

Key words

ANALGESICS: morphine, fentanyl;

ANAESTHETICS INTRAVENOUS: morphine, fentanyl.

From the Department of Anesthesiology, School of Medicine, University of Alabama in Birmingham, Birmingham, Alabama

Address correspondence to: Dr. I. Kissin, Dept. of Anesthesiology, School of Medicine, University of Alabama in Birmingham, Birmingham, Alabama 35294.
The use of high doses of narcotic analgesics to achieve desired anaesthetic objectives is becoming a current practice in anaesthesia. Some narcotic analgesics are now used as sole (complete) intravenous anaesthetics. Stanley has classified these agents as intravenous narcotic anaesthetics. ' Pharmacological evaluation of narcotics used for anaesthesia is usually performed with methods developed for assessment of analgesia. The objective of our study was to assess the effects of narcotic analgesics using methods that we previously applied for the assessment of non-narcotic intravenous anaesthetics. ${ }^{2}$ Potencies of morphine and fentanyl were evaluated using three indices: loss of righting reflex (RR), abolition of purposeful movement response to a noxious stimulus (PM), and abolition of increase in heart rate in response to a noxious stimulus (HR).

\section{Methods}

The experiments were done on 150 male SpragueDawley rats weighing $225-250 \mathrm{~g}$. Morphine and fentanyl dose-effect curves were determined by the following criteria: (1) Loss of righting reflex. The test was regarded as positive if the rat failed to right itself (with all four feet on the table) within $15 \mathrm{~s}$ after being placed in a side position. (2) Prevention of purposeful movement response to a noxious stimulus. The animals were stimulated for $60 \mathrm{~s}$ by placement of a haemostat on the middle of the tail (pressure of $25 \mathrm{~kg}$ on the tail surface of $0.25 \mathrm{~cm}^{2}$ ). Purposeful movement toward the clamp was considered a positive response to the stimulation. Since the movement usually finished with clamp biting the method was very similar to Haffner's method, ${ }^{3}$ and may be regarded as a test for analgesia. (3) Prevention of a rise in heart rate in response to a noxious stimulus. Stimulation was the same as for the movement response. The heart rate was obtained 
from an electrocardiogram. A special microcomputerbased cardiotachometer counted the number of beats during a $15 \mathrm{~s}$ time interval with the output updated every $5 \mathrm{~s}$. The cardiotachometer provided records of heart rate on a Grass 7-D polygraph. An increase in heart rate of greater than one per cent was considered to be a positive response to the noxious stimulus.

With each of the two narcotics, three series of experiments were done (for RR, PM, and HR). Since the blockade of the responses was achieved at very different levels of agent doses, in two series of experiments (RR and HR) it was necessary 10 prevent respiratory depression. Therefore, in the righting reflex series, the animals were kept in a clear chamber and oxygen was directed into the chamber at a rate of $4 \mathrm{l} / \mathrm{min}$. Under these conditions, $\mathrm{PaO}_{2}$ was always more than $100 \mathrm{mmHg}$. In the heart rate response series, the animals were intubated and kept on controlled ventilation. In the latter, immediately after injection of the analgesic, tubocurarine chloride ( $1 \mathrm{mg} \cdot \mathrm{kg}^{-1}$ IV) was administered and an endotracheal tube was inserted with the use of a laryngoscope. ${ }^{4}$ Ventilation rate was maintained at 60/min (Harvard S-680 Rodent Respirator) with tidal volume adjusted to maintain $\mathrm{PaCO}_{2}$ at 40 $\pm 5 \mathrm{mmHg}(2.0-2.4 \mathrm{ml})$.

Morphine sulphate (Merck) and fentanyl citrate (Janssen) were injected into the saphenous vein over $10 \mathrm{sec}$. Volume of the injected solution was $0.5-1.0 \mathrm{ml}$. In each series of experiments, five doses were administered, each in a group of five rats. In one group of animals, the dose of the drug was low enough so that all animals were unaffected, and in another group, it was high enough so that all were affected. Dose levels for these two groups were determined in preliminary experiments. In the three remaining groups, the doses of the drug were spaced between the above mentioned marginal doses. As a result, the following doses were used. In the morphine series $\left(\mathrm{mg} \cdot \mathrm{kg}^{-1}\right)-3,4,6,8,10$ for $\mathrm{PM} ; 3,4,6,8,10$ for $\mathrm{HR} ; 35,40,45,50,55$ for $\mathrm{RR}$; and in the fentanyl series $\left(\mu \mathrm{g} \cdot \mathrm{kg}^{-1}\right)-5,7.5,10$, $12.5,15$ for PM; $18,20,22,25,30$ for RR; 200, $250,300,350,400$ for HR.

The end points were determined five minutes after injection of fentanyl and 15 minutes after injection of morphine. The difference in the time periods is due to the fact that fentanyl is a bighly lipophilic agent, as compared to morphine, and
TABLE I ED50 Results

\begin{tabular}{|c|c|c|c|c|}
\hline & End point & $N$ & $\begin{array}{l}E D 50 \\
\left(m g \cdot \mathrm{kg}^{-1} \mathrm{~N}\right)\end{array}$ & $\begin{array}{l}\text { Relative } \\
\text { potency }\end{array}$ \\
\hline \multirow{4}{*}{ Morphine } & PM & 25 & $5.8(4.4-7.1)$ & 1 \\
\hline & RR & 25 & $45.2(40.4-51.0)$ & 1 \\
\hline & HR & 25 & $5.9(4.5-8.0)$ & 1 \\
\hline & $\mathrm{TW}$ & 一 & $3.5(2.0-6.2)$ & I \\
\hline \multirow{4}{*}{ Fentany] } & $\mathrm{PM}$ & 25 & $0.009(0.007-0.011)$ & 644 \\
\hline & RR & 25 & $0.023(0.020-0.026)$ & 1965 \\
\hline & $\mathrm{HR}$ & 25 & $0.312(0.220-0.624)$ & 20 \\
\hline & ( TW & - & $0.013(0.008-0.020)$ & 269 \\
\hline
\end{tabular}

PM - purposeful movement response to painful stimulus.

$\mathbf{R R}=$ righting reflex. $\mathbf{H R}=$ increase in heart rate in response to pain[ul stimu]us.

TW = tail withdrawal reftex as reported by Janssen et al. (s.c. injection). ${ }^{4}$

Number in parenthesis indicates 95 per cent fiducial limits.

$\mathrm{N}=$ number of animals used to detemine dose-effect curve.

therefore, more rapidly penetrates membranes including the blood-brain barrier. ${ }^{5}$ As a result, the time of peak effect is different for these agents. In our preliminary experiments, peak effect for morphine and fentanyl were determined with the use of tail withdrawal reflex induced by immersing the end of the tail of a rat in $55^{\circ} \mathrm{C}$ water. ${ }^{6}$ Two groups of five rats were used, one for morphine and one for fentanyl. The peak time in the fentanyl group was five minutes; in the morphine group, 15 minutes. These results are consistent with the data of other investigators. ${ }^{7}$

For calculation of dose-effect curves, we used the probit method of statistical analysis. The percentage of positive effects was converted into probit values (multiples of the standard deviation) and plotted against the log of doses. This converts the sigmoid dose-effect curve into a straight line and facilitates comparisons. All calculations were performed with the use of the probit procedure in $\mathrm{SAS}^{8}$ on an IBM 370 computer. The procedure was a non-linear least squares technique based on the method of Finney, ${ }^{9}$ ED1-ED99 data for righting reflex (RR), purposeful movement response (PM), and heart rate increase (HR) were derived. Potency ratios, RR ED50/PM ED50 and HR ED50/PM ED50, were obtained for both agents. The ratios were tested using analysis of variance of the linear combination of the logarithms of the EDS0 values. Estimates of $\log$ ED50 and its variance were ob- 


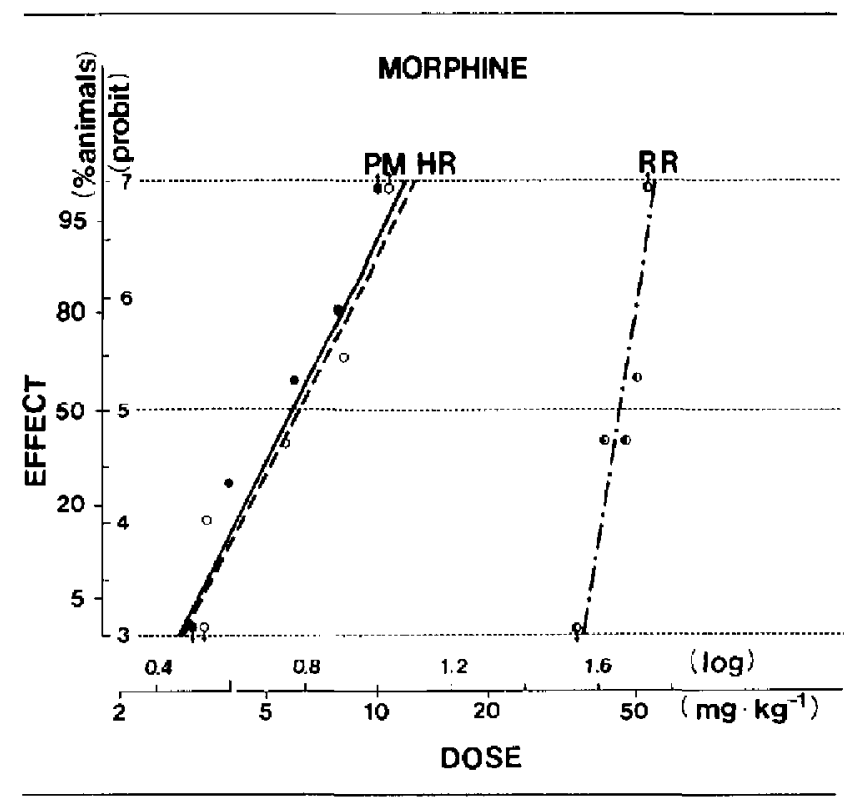

FIGURE । Morphine dose-effect curves for different end points of anaesthesia. The ordinate represents the per cent of animals (on a probit scale) that reached the specified end points. Fach dot represents the incidence of effect in a group of five animals at the indicated dosage. PM = prevention of purposeful movement in response to a noxious stimulus (solid dots). $\mathrm{RR}=$ loss of righting reflex.

$\mathrm{HR}=$ prevention of heart ratc increase in response to a noxious stimulus (open dots).

tained from the parameters of the regression using Fieller's theorem. ${ }^{\text {' }}$

Animal care standards in this study were in accordance with federal, and institutional policy and standards of the American Association for Accreditation of Laboratory Animal Care as specified in the Guide for the Care and Use of Laboratory Animals. ${ }^{10}$

\section{Resulits}

Figures 1 and 2 show morphine and fentanyl dose-effect curves. Central points of the curves represent the median effective doses (ED50), Table I. With both morphine and fentanyl, the ED50 values for righting reflex were greater than those for purposeful movement response, which is typical for analgesic agents. However, the ratios of RR ED50 to PM ED50 for morphine and fentanyl were different $(7.8$ vs $2.6, \mathrm{p}<0.001$, Table $I)$. The most striking difference between morphine and fentanyl was evident in the comparison of doses blocking the heart rate response. With morphine, the HR dose-effect curve was not significantly different from the PM curve; with fentanyl, it was shifted far to the right along the dose axis beyond the RR curve (Figs. 1 and 2). As a result, the ratios of HR ED50 to PM ED50 were 1.0 for morphine and 34.7 for fentanyl ( $p<0.001$, Table II).

\section{Discussion}

Our morphine ED 50 value $\left(5.8 \mathrm{mg} \cdot \mathrm{kg}^{-1}\right)$ for purposeful movement response is very close to those obtained with the Haffner method $\left(5.7 \mathrm{mg} \cdot \mathrm{kg}^{-1}, 11\right.$

TABLE II Potency ratios of morphine and fentany]

\begin{tabular}{lll}
\hline & $\frac{R R E D S 0}{P M E D 50}$ & $\frac{H R E D 50}{P M E D 50}$ \\
\hline Morphine & 7.8 & 1.0 \\
Fentanyl & $2.4^{*}$ & $33.0^{*}$ \\
\hline
\end{tabular}

${ }^{*} p<0.001$ (morphine vs fentanyl). 


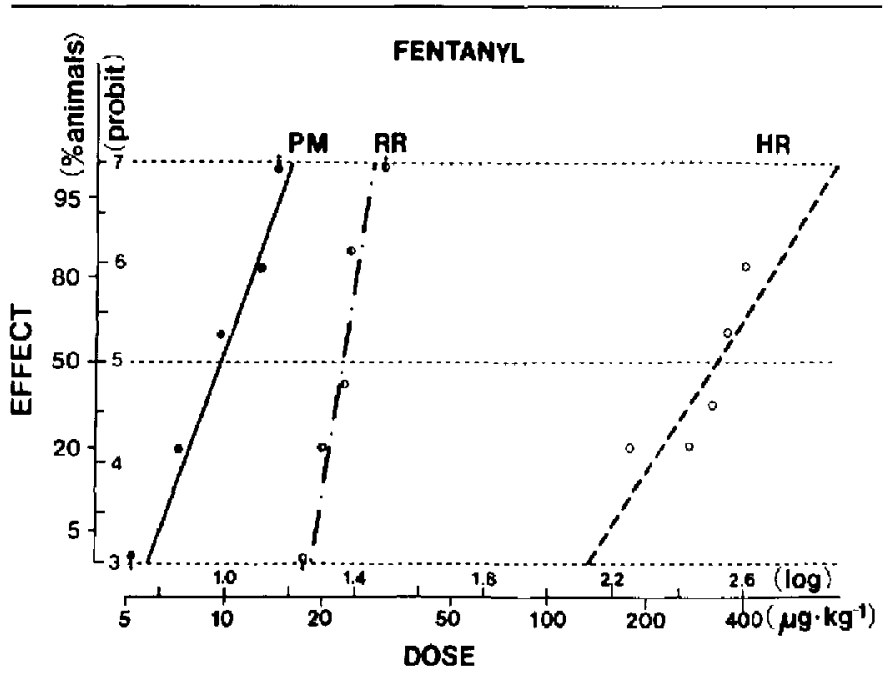

FIGURE 2 Fentanyl dose-effect curves for different end points of anaesthesia.

and $7.0 \mathrm{mg} \cdot \mathrm{kg}^{-1},{ }^{12}$ s.c., mice) and somewhat greater than with the tail withdrawal method $\left(3.5 \mathrm{mg} \cdot \mathrm{kg}^{-1}\right.$, s.c., rats). ${ }^{6}$ The absence of reaction is taken into account in the Haffner method, but with the tail withdrawal method, only an increase in reaction time is considered. Close agreement between the above results suggests that the purposeful movement response used in our study correctly reflected analgesic potency.

When considering the analgesic potency and anaesthetic action, we used these terms with the following meanings. Analgesic potency of an agent - strength of action determined on the basis of the agent's ability to block motor response to noxious stimulation in a conscious subject and measured in dose units. Anaesthetic action - action that results in the achievement of the following goals of anaesthesia: unconsciousness, motor (somatic) unresponsiveness to surgical stimulation, and autonomic unresponsiveness to surgical stimulation. It is commonly held that blockade of the sympathetic responses to surgical stimulation is one of the most important goals of anaesthesia. In the present study, we demonstrated that while morphine blocks heart rate (sympathetic) and purposeful movement (somatic) responses at doses of the same level, fentanyl blocks heart rate response in doses that are about 35 times larger than doses needed for blockade of purposeful movement response. This leads to the following suggestions.

First, the analgesic potency of an intravenous narcotic anaesthetic may not reflect the strength of its anaesthetic action, specifically in achievement of autonomic unresponsiveness to surgical stimulation. Some additional evidence in this respect may be found in comparing doses of morphine and fentanyl when they are used in clinical practice as sole anaesthetics. Doses of morphine for this indication are $1-3 \mathrm{mg} \cdot \mathrm{kg}^{-1}$ and doses of fentanyl are $0.05-0.10 \mathrm{mg} \cdot \mathrm{kg}^{-1}{ }^{1,13}$ The morphine-fentanyl ratio of potency in this case is about 1:20-1:30. This ratio is many times less than the analgesic morphine-fentanyl potency ratio. Janssen et al. ${ }^{6}$ reported that morphine-fentanyl potency ratio equals 1:269. In our experiments, with the use of heart rate increase to noxious stimulus as an end-point of anaesthesia, the morphine-fentanyl ratio was $1: 20$ (Table I) which is very similar to the ratio obtained from doses in which the agents are used as sole anaesthetics. With this similarity, it should be taken into consideration that in clinical practice, the main index of anaesthesia that ultimately determines the level of doses used is also heart rate (or arterial pressure) increase in response to surgical stimulation. Blockade of movement response to noxious stimulation (which is usually 
regarded as an index for analgesic action for opioids) and blockade of heart rate response (which is one of the goals of anaesthesia) is not necessarily induced by intravenous narcotic anaesthetics through the same mechanisms. The involvement of various subtypes of opioid receptors ${ }^{14}$ should be considered in this regard.

Second, the large dissociation between blockade of purposeful movement response and heart rate response in the effect of fentanyl suggests that the heart rate increase in response to noxious stimulation does not necessarily always have a direct relationship to the feeling of pain. An increase in heart rate when there is no movement in response to noxious stimulation should probably be regarded as just a reflex from the same receptors which are activated in pain (i.e., nociceptive reflex).

Comparison of the effects of studied agents regarding the three indices used has shown that the difference in potencies between fentanyl and morphine is most pronounced with the righting reflex (1965 vs 644 for PM and 20 for HR). Wide variability in relative potencies also implies that the end-points used may be reached by morphine and fentanyl through different mechanisms.

Thus, the present investigation demonstrated that potency ratios of morphine and fentanyl are different for various end points studied, suggesting that the indices of analgesic potency of intravenous narcotic anaesthetics may not reflect the strength of their anaesthetic action.

\section{Acknowledgement}

The authors thank Thomas C. Jannett, M.S., who devised the microcomputer-hased cardiotachometer used in this study.

\section{References}

1. Stanley TH. Pharmacology of intravenous narcotic anaesthetics. In: Anaesthesia, edited by Miller RD. New York, Churchill Livingstone, 1981, p. 425.

2. Kissin l, McGee T, Smith LR. The indices of potency for intravenous anaesthetics. Can Anaesth Soc J 1981; 28: 585-9.

3. Haffner $F$. Experimentalle prufung schmerzstillender mittel. Dtșch Med Wschr 1929; 55: 731-3.

4. Morgan PL. A modified laryngoscope blade for rat intubation. Anesthesiology 1982; 57: 431.

5. McClain DA, Hug CC. Intravenous fentanyl kinetics. Clin Pharmacol Ther 1980; 28: 106-13.

6. Janssen PAJ, Niemegeers CJE, Dony JGH. The inhibitory effect of fentanyl and other morphine-like analgesics on the warm water induced tail withdrawal reflex in rats. Arzneimit Forsch 1963; 13: 502-7.

7. Dahlstroem BE, Paalzow L. Pharmacokinetics of morphine in relation to analgesia: effects of routes of administration. In: Factors Affecting the Action of Narcotics, edited by Manara, A.L. and Samanin, R. New York, Raven Press, 1978, pp. 233-41.

8. SAS Users Guide. The SAS Institure, Raleigh, N.C. (1979).

9. Finney DJ. Probit analysis. London, Cambridge University Press (1952).

10. Guide for the Care and Use of Laboratory Animals. DHEW Publication Na. (NIH)78-23, Washington, U.S. Goverment Printing Office, 1978.

11. Bianchi $C$, Franceschini J. Experimental observations on Haffner's method for testing analgesic drugs. Br J Pharmacol 1959; 9: 280-4.

12. Kissel JW, Albert JR, and Boxill GC. The pharmacology of prodilidine hydrochloride, a new analgetic agent. J Pharmacol Exp Ther 1961; 134: $332-40$.

13. Lowenstein E, Philbin DM. Narcotic "anesthesia" in the eighties. Anesthesiology 1981; 55: 195-7.

14. Martin WR, Eades CG, Thompson JA, Huppler RE, Gilbert $P E$. The effects of morphine and nalorphine like drugs in the non-dependent and morphinedependent chronic spinal dog. J Pharmacol Exp Ther 1976; 197: 517-32. 
Rèsumé

Chez 150 rats de race Sprague-Dawley, on a déterminé les courbes dose-réponse de la morphine et du fentanyl pour les trois niveaux-cibles suivants: inhibition de mouvement intentionnel en réponse à un stimulus nocif (PM), perte du réflex de redressement (RR) et prévention de la tachycardie d la suite d' un stimulus nocif (HR). A cette fin, pour chacun des agents, on a effectlé trois séries d'expériences consistant en administration intraveineuse des doses suivantes: morphine $3-10 \mathrm{mg} \cdot \mathrm{kg}^{-1}$ pour PM, 3-10 mg $\mathrm{kg}^{-1}$ pour HR, 35-55 $\mathrm{mg} \cdot \mathrm{kg}^{-1}$ pour RR; fentanyl 5-15 $\mu \mathrm{g}^{\mathrm{kg}} \mathrm{kg}^{-1}$ pour PM, 18-30 $\mathrm{\mu g} \cdot \mathrm{kg}^{-1}$ pour $R R, 200-400 \mu \mathrm{g} \cdot \mathrm{kg}^{-1}$ pour HR. Les courbes doseréponse ont été converties par la méthode probit, c'est-àdire que les pourcentages d'effets positifs ont été exprimés en probit qui sont des multiples de l'écart-type et portés sur les graphiques en regard du logarithme des doses; cette opération transforme la courbe dose-réponse qui est sigmoïde en ligne droite et facilite les comparaisons. Les ratios de puissance ont été déterminés a partir des valeurs de EDSO.

On a rrouvé que les rarios de puissance de la morphine et du fentanyl diffèrent pour les effets-cibles étudiés. Les rapports de RR EDSO sur PM ED50 étaient 7.8 pour la morphine contre 2.4 pour le fentanyl ( $p<0.001$ ), les ratios HR ED5O sur PM EDSO étaient 1 et 33 respectivement $(p<0.001)$. Ces résultats laissent entendre que le mécanisme par lequel la réponse motrice intentionnelle est suspendue n'est pas nécessairement le même qui prévient laccélération de la fréquence à la suite de stimulation nocive. Conséquemment, la dose d' un opiacé administrée par voie intraveineuse capable de prévenir la réponse motrice intentionnelle à un stimulus nocif peut bien être insuffisante pour prévenir la réponse du systèrne nerveux autonome da la stimulation chirurgicale. 